\title{
Cross-cultural adaptation, reliability, and validity of the Japanese version of the Cumberland ankle instability tool
}

SHUN KUNUGI ${ }^{\mathrm{a}}$, AKIHIKO MASUNARI ${ }^{\mathrm{a}}$,, , BYUNGJOO NOH ${ }^{\mathrm{c}}$, TOSHIO MORI ${ }^{\mathrm{a}}$, NARUTO YOSHIDA ${ }^{\mathrm{d}}, \&$ SHUMPEI MIYAKAWA ${ }^{\mathrm{a}^{*}}$

${ }^{a}$ Department of Sports Medicine, Graduate School of Comprehensive Human Sciences, University of Tsukuba, Ibaraki, Japan; ${ }^{b}$ Center for Medical Sciences, Ibaraki Prefectural University of Health Sciences, Ibaraki, Japan; ${ }^{c}$ Department of Kinesiology and Integrative Physiology, Michiga Technology University, Michigan, USA; ${ }^{\mathrm{d}}$ Faculty of Health Care, Teikyo Heisei University, Tokyo, Japan

* Corresponding author:

Shumpei Miyakawa MD, PhD

Laboratory of Sports Medicine

Department of Sports Medicine, Graduate School of Comprehensive Human Sciences University of Tsukuba

1-1-1 Tennodai, Tsukuba 305-8574, Japan

E-mail: miyakawa@taiiku.tsukuba.ac.jp

Fax: +81-29-853-2575

Phone: +81 29-853-2575

Key words: CAIT; cross-cultural adaptation; Japanese version, reliability and validity 


\section{ABSTRACT}

Purpose To study validity and reliability of a Japanese version of the Cumberland Ankle Instability Tool and to determine the optimal cut-off score.

Methods In this study, the questionnaire was cross-culturally adapted into Japanese. The psychometric properties tested in the Japanese version of the CAIT were measured for criteria validity, internal consistency and test-retest reliability in 111 collegiate soccer athletes. We also established the questionnaire cut-off score for discriminating between individuals with and without CAI.

Results There was a significant correlation between the Japanese version of the CAIT and the Karlsson score $(r=0.604, p<0.001)$. The questionnaire had a high internal consistency (Cronbach's $\alpha=0.833)$ and reliability [intraclass correlation coefficient $(\mathrm{ICC})=0.826,95 \%$ confidence interval $(\mathrm{CI})$ : $0.732-0.888$ ]. The optimal cut-off score was $\leq 25$, which was consistent with previous reports.

Conclusions The Japanese version of the CAIT has been shown to be a valid and reliable questionnaire for determining the presence of CAI. We expect that researchers and clinicians will use the Japanese version of the CAIT in Japan.

\section{Implications for Rehabilitation}

- Chronic Ankle Instability (CAI), which not only increases recurrence rate of ankle sprain but also decreases athletic performance, is a residual symptom after ankle sprain.

- Cumberland Ankle Instability Tool, which has the reliability and validity to assess CAI, 
will be critically useful in assessment procedure for CAI.

- It is preferable for clinicians and researchers to use the native language version of the CAIT. 


\section{Introduction}

Ankle sprain is one of the most common injures in sports activities. The incidence and recurrence rate of ankle sprain is high in team sports such as soccer. [1,2] As many as $73 \%$ of all athletes have recurrent ankle sprain and $59 \%$ of these athletes have significant disability and residual symptoms impairing their athletic performance. [3] Approximately $20-30 \%$ of athletes with acute ankle sprains develop mechanical ankle instability (MAI) and/or functional ankle instability (FAI), resulting in residual symptoms called chronic ankle instability (CAI). [4,5] Athletes with FAI show impairment on jump performance that demands a change of direction, such as a side hop and figure-8 hop. [6] The impairment in this athletic performance result from eversion muscle weakness, diminished proprioception [7] and impaired postural control. [8] These impairments are associated with a significantly increased risk of ankle sprain. [9] On the other hand, athletes with MAI have mechanical insufficiencies, including pathological laxity, and impaired arthrokinematics. They have the potential of synovial and degenerative changes. [10] However, FAI and MAI are present in CAI, and both are not completely independent and should be assessed together. [11]

Pathologic laxity is assessed clinically by physical examination such as a manual test and stress

radiography. [12] Examination of stress using MRI also has advantages in the assessment of mechanical instability. [13] Quantitative and visible evaluation with diagnostic imaging permits measurement of the severity of MAI. However, functional instability has been difficult to quantitatively measure. In Japan, the Karlsson score [14] and the Japanese Society for Surgery of the Foot standard rating system $[15,16]$ have been used to subjectively assess FAI or CAI. [17] Although another questionnaires to assess CAI are used 
in many studies, [17] these questionnaires have not been translated into Japanese. The inconsistency in participant selection criteria across studies presents a potential obstacle to collectively assess CAI. Thus, standards for participant selection criteria are required.

Hiller et al. [18] developed the Cumberland Ankle Instability Tool (CAIT; Appendix 1), which is a reliable and valid questionnaire for identifying patients with FAI. The CAIT is a 9-item questionnaire that is designed to evaluate several aspects of FAI. The total score of the 9 items ranges from 0 (severe instability) to 30 (normal stability). The International Ankle Consortium recommends that self-reported ankle instability should be confirmed using valid and reliable questionnaires such as the CAIT. [19] Hence the CAIT will be used in various countries because it has already been translated into Portuguese [20] and Spanish. [21] However, the CAIT has some problems that include the use of various independently selected cutoff scores (i.e. $\leq 23, \leq 24, \leq 25$ and $\leq 27)[18,22-24]$ to determine CAI. In addition, the questionnaire was developed in English, thereby limiting its applicability to English speakers. There are several populations that do not speak English and are consequently unable to use the English CAIT. In the case of that clinicians and researchers assess a patient for CAI in this fields, it is reliable and valid that they use a native language questionnaire and standard criteria for CAIT cutoff score. In Japan, some researchers $[25,26]$ have used a questionnaire that was written in English to identify participants with CAI. However, the questionnaire has not been shown to be valid and reliable. Therefore, the purpose of this study was to develop a Japanese version of the CAIT and to determine the cutoff score. 


\section{Materials and methods}

\section{Adaptation procedures}

Translation of the English CAIT into Japanese was performed using the guidelines for the process of cross-cultural adaptation of self-reports measures [27] as a reference. Two bilingual experts were Japanese, one who was a medical doctor and the other who was a NATA-certified athletic trainer, each translated the English CAIT into Japanese. Differences in the translation were discussed and a consensus was reached. Back-translation was conducted by another bilingual translator who was blinded to the original English CAIT. Differences in the two versions were discussed and a consensus was reached. Finally, some modifications were made to correct cultural differences and to preserve equivalence with the English version of the CAIT. For example, the term "on the ball of my foot" was translated as "on the tip of their toes", which means generally "on the fore fleshy part of my foot" in Japanese. In addition, the term "hopping" was translated into Japanese as "jumping on one leg". The Japanese version of the CAIT is presented in Appendix 2.

\section{Participants}

A total of 111 native Japanese speakers were recruited from a university men's soccer club and the following those male soccer players were included in this study: CAI group (61 participants with CAI) and Control group (50 control participants). The inclusion criteria for the CAI group included a history of at least two severe ankle sprains and reported episodes of a feeling of ankle instability and/or "giving way" 
and/or chronic pain in the ankle during daily life or sports activity. These inclusion criteria were determined on the basis of previous studies. $[28,29]$ The Control group had none of the above ankle issues. The exclusion criteria were based on previous studies $[19,30]$ and included the following: (a) a history of previous surgery of musculoskeletal structures and fracture requiring realignment of either limb of the lower extremity, (b) acute injury to the musculoskeletal structures of the other lower extremity joints in the previous 3 months, which impacted joint integrity and function, resulting in at least one day of interrupted desired physical activity, and (c) performing balance training on a routine basis. In case of the participants had bilateral CAI, the self-reported more unstable ankle were included in the CAI group. The Japanese version of the CAIT and the Karlsson score were not used as inclusion criteria for any group. Participant demographics are described in Table 1 . To assess reliability, 41 of the 111 participants included in the retest group (Table 2), which corresponded to 82 feet (Table 2), answered about both legs and completed a retest of the Japanese version of the CAIT 3 weeks after the initial test. The individuals in the retest group had not injured themselves in the previous 3 weeks.

This study was approved by the University of Tsukuba's Comprehensive Human Sciences Ethical Committee. All subjects provided written or oral consent to participate in the study after being provided with an explanation of the study's intent and methods (No.26-75).

\section{Psychometric properties and discriminative ability}

To assess for validity and reliability three psychometric properties of the Japanese version of the CAIT 
were analysed: criterion-related validity, internal consistency, and test-retest reliability. Validity was assessed by criterion-related validity whether the Japanese version of the CAIT correlated with a related questionnaire for CAI. Reliability divided into consistency and repeatability was assessed by internal consistency and test-retest reliability, respectively. Discriminative ability was assessed to determine whether the Japanese version of the CAIT could distinguish between subjects with and without CAI.

Criterion-related validity. The criterion-related validity of the Japanese version of the CAIT was assessed using the Karlsson score. Both questionnaires were administered to both groups. The Karlsson score as an external criterion was written in comparatively simple English and designed to evaluate the ankle joint stability and function. The Karlsson score is an 8 -item questionnaire and the total score of the 8 items ranges from 0 to 100 . A score of $\geq 80$ points is classified as an acceptable (excellent or good) result, whereas a score of $<79$ points is classified as an unacceptable (fair or poor) result. [14] The scoring scale is a useful aid to assess ankle joint function in a standardized manner. Therefore, the questionnaire has been used to evaluate FAI in some studies targeted towards Japanese people. [26,31]

Internal consistency. The Internal consistency of the Japanese version of the CAIT was assessed using Cronbach's $\alpha$ coefficient. [32] A questionnaire is considered internally consistent if the item are at least moderately correlated with each other and each item is correlated with the total score $(\alpha=0.75-0.95)$. [32] In the retest group the Japanese version of the CAIT score of the first test was used for this analysis. 
Test-retest reliability. To determine test-retest reliability, the Japanese version of the CAIT was

administered to a retest group of 41 participants, which corresponded to 82 feet, 3 weeks after the initial test. Test-retest reliability was assessed using the intraclass correlation coefficient $\left(\mathrm{ICC}_{2.1}\right)$. For this analysis, we used scores obtained in the first and second tests for patients in the retest group who completed the Japanese version of the CAIT.

Discriminative ability. Discriminative ability was tested to determine whether the Japanese version of the CAIT could distinguish between subjects with and without CAI. A receiver operating characteristic (ROC) curve [33] was constructed to confirm the cutoff point of the Japanese version of the CAIT. The cutoff point was determined using the Youden index. [34] For this analysis, we used scores obtained in the first test for all participants who completed the Japanese version of the CAIT and data with or without CAI defined in this study.

\section{Statistics}

All analyses were conducted using SPSS version 21 (Chicago, IL). Paired $t$-tests were used to compare participants' demographics between groups.

Criterion-related validity. Criterion-related validity was assessed using Spearman's correlation coefficient between the Karlsson score and the Japanese version of the CAIT. The Spearman's correlation coefficient were as follows: poor, $<0$; slight, $0.00-0.20$; fair, $0.21-0.40$; moderate, $0.41-0.60$; substantial, 0.61-0.80 and almost perfect, $>0.81$. [35] 
Internal consistency. Internal consistency was assessed using Cronbach's $\alpha$ coefficient. A positive rating for internal consistency was considered when factor analysis was applied and Cronbach's $\alpha$ coefficient was between 0.70 and 0.95 . [32]

Test-retest reliability. Test-retest reliability was assessed using the intraclass correlation coefficient $\left(\mathrm{ICC}_{2.1}\right)$ as reference previous study. [20] The $\mathrm{ICC}_{2.1}$ scores were as follows: poor, $<0$; slight, $0.00-0.20$; fair, 0.21-0.40; moderate, 0.41-0.60; substantial, $0.61-0.80$ and almost perfect, $>0.81$. [35]

Discriminative ability. An ROC curve was constructed with the "Japanese version of the CAIT" as a dependent variable and "group member" (CAI group or Control group) as the independent variable. To identify a significant ROC curve, the area under the curve (AUC) was calculated using a one-tailed test. After calculating the diagnostic sensitivity and specificity for each potential cutoff score, the ideal cutoff point was determined using the maximum Youden index, which was calculated as follows: sensitivity + specificity -1 .

Each cutoff score was evaluated using the positive likelihood (LR+) [sensitivity/(1 - specificity)] and the negative likelihood $\left(\mathrm{LR}^{-}\right)$[(1 - sensitivity)/specificity].

Statistical significance was set at $<5 \%$.

\section{Results}

There were no significant differences in demographic characteristics between the CAI and Control groups.

The demographic characteristics are presented in Table 1. 


\section{Criterion-related validity}

Criterion-related validity was assessed using Spearman's correlation coefficient. There was a moderate correlation between the Japanese version of the CAIT and the Karlsson score $(r=0.604, p<0.001$; Figure $1)$.

\section{Internal consistency}

Cronbach's $\alpha$ coefficient for the Japanese version of the CAIT score showed a high internal consistency

(0.833). Cronbach's $\alpha$ coefficient if each item was deleted and each correlation coefficient between the score of each item and total scores except the each item were shown in Table 3. In the item analysis, no improvement was observed each time a particular item was deleted from the scale, except for item 9, which showed a slight increase when it was omitted (Table 3).

\section{Test-retest reliability}

In the retest group, the mean first and second test scores of the Japanese version of the CAIT were 27.38

SD 3.10 and 27.93 SD 3.29, respectively. The Japanese version of the CAIT had almost perfect reliability

$\left[\mathrm{ICC}_{2.1}=0.826 ; 95 \%\right.$ confidence interval $\left.(\mathrm{CI}): 0.732-0.888, p<0.001\right]$.

\section{Discriminative ability}

The mean scores of the Japanese version of the CAIT for the CAI group $(n=61)$ and Control group $(n=$

51) were 22.56 SD 4.89 and 28.42 SD 1.65, respectively (Table 1). The ROC curve showed that the Japanese version of the CAIT score significantly discriminated between the groups (AUC $=0.932, p<$ 0.001). The ROC curve is shown in Figure 2. The maximum Youden index (0.685) indicated that the 
Japanese version of the CAIT score of 25 was the cutoff point to distinguish between the groups. High sensitivity $(0.705)$ and specificity $(0.980)$ were calculated at the cutoff point. The LR+ and LR- values were 35.35 and 0.30 , respectively (Table 4 ).

\section{Discussion}

The CAIT was developed in English, thereby limiting its applicability to English speaking populations; non-English speakers are unable to use the English CAIT. Previous research in Japan has shown that some questionnaires written in English were used to assess CAI. However, the participants were Japanese speakers rather than English speakers. Few tools are available to assess CAI in Japanese speakers.

Therefore, our goal was to translate the CAIT into Japanese and to assess the questionnaire's validity, reliability and discriminative ability. Translation was performed using a guideline, and some changes were made and some terms were added. Compared with the English CAIT, no significant differences were observed in the psychometric property of the translated CAIT. Therefore, it was shown that the Japanese version of the CAIT was a reliable and valid questionnaire.

Criterion-related validity was assessed between the Karlsson score and the Japanese version of the CAIT using Spearman's correlation coefficient. The questionnaire had a moderate correlation with the Karlsson score. A previous study has shown that there is a high correlation between the CAIT and subject's overall perception of ankle instability. [18] The Karlsson score is also an assessment tool for ankle joint function, and thus, there is a correlation with the Japanese version of the CAIT. 
Cronbach's $\alpha$ coefficient of the Japanese version of the CAIT was 0.833 . A coefficient value from 0.70 to 0.95 represents very good internal consistency. [32] The coefficient of the English CAIT is 0.83 [18] and that of the Brazilian Portuguese version is $0.86-0.88,[20]$ which is approximately equal to that obtained in this study. To determine the influence of each item on Cronbach's $\alpha$ coefficient, we systematically excluded each item from the Japanese version of the CAIT. The coefficient was slightly increased when item 9 was deleted, but no improvement was observed for the rest of the items. In the Spanish version of the CAIT, Cronbach's $\alpha$ coefficient was slightly increased when items 5 and 6 were deleted, because items 5 and 6 refer to unusual activity such as feeling unstable when standing on one leg or hopping from side to side. [21] In contrast, no individual items were inserted into the instrument in the Brazilian Portuguese version of the CAIT. [20] In our study, no improvement was observed when each of items 5 and 6 were deleted, which may be because all participants were collegiate soccer athletes who performed these movements, such as standing on one leg and hopping from side to side, on a daily basis. Moreover, deleting item 9 slightly increased Cronbach's $\alpha$ coefficient because item 9 , which is strongly influenced by memory, might be weakly relevant in case of present ankle stability.

Test-retest reliability of the Japanese version of the CAIT was assessed using $\mathrm{ICC}_{2.1}$ with the initial and follow-up score in the retest group. The $\mathrm{ICC}_{2.1}$ value was 0.826 with a $95 \% \mathrm{CI}$ of $0.732-0.888$ ( $p<$ 0.001). The value was classified as 'almost perfect' according to Landis's classification, but slightly inferior to the value of the English version (0.96), [18] Brazilian Portuguese version (0.95) [20] and Spanish version (0.979) [21] of the CAIT. In these studies, the interval of the tests was 1 or 2 weeks; in 
contrast, the present study was longer than these intervals. On testing repeatability, the subject's memory influences the second test, particularly when the term is short; however, a long term may alter the state of the subject's memory. Thus, the reliability of the Japanese version of the CAIT is slightly inferior to that of the other versions.

The discriminative ability and cut-off score of the Japanese version of the CAIT was determined by describing the ROC curve $(\mathrm{AUC}=0.932)$ and calculating the Youden Index (maximum index: 0.685$)$ at a score of 25.5. The sensitivity (0.705), specificity (0.98), LR+ (35.35) and LR- $(0.30)$ were calculated at this cut-off score. Hiller et al. (2006) showed that for the English CAIT, a score of $\leq 27$ was the cut-off to distinguish between participants with and without a history of ankle sprain. However, to distinguish between CAI and uninjured groups, Wright et al. [24] recalibrated the ideal cut-off score to $\leq 25$, which was the same as the score of the Japanese version. The high sensitivity (0.951) and specificity (1.000), LR+ (not applicable) and LR- (0.049) of the English CAIT were calculated at a score of 25.5. LR+ was not calculated at this score, and the next nearest cut-off value resulted in an LR+ of 27.171. The clinimetric properties are described in Table 5. LR+ of the Japanese version of the CAIT was slightly higher than that of the English CAIT. Therefore, the questionnaire may more accurately select patients with CAI. However, LR - was 0.30 , which is an inadequate score to identify patients without CAI. Although the Japanese version of the CAIT score of $\leq 25$ has some differences from English version, this is the optimal cut-off to distinguish between patients with and without CAI.

\section{Study limitations}


The present study has some limitations. First, MAI of the participants was not assessed using an objective assessment of structures, such as stress X-ray. MAI influences the unstable feeling with and without FAI, and thus, the CAIT score may be affected by the presence and absence of MAI. Moreover, copers [36] who have a history of ankle sprain but no ongoing instability were not classified in this study. Wright et al. [24] showed that the ideal CAIT cutoff score was slightly lower when copers were divided into those with CAI and those who were uninjured, compared with when they were not divided. Similarly, the score of the Japanese version may change when copers are separated from those with other ankle statuses. Although FAI and MAI were not completely independent, MAI and copers should be separated from CAI in future research. These approaches may more rigorously identify the severity of ankle instability.

\section{Conclusions}

The Japanese version of the CAIT is a valid and reliable questionnaire for assessing CAI. The ideal cutoff score to assess the presence or absence of CAI is 25 . In addition, the questionnaire can be easily applied and can immediately and correctly provide clinicians and researchers with the patient's ankle status. In Japan, it is preferable for clinicians and researchers to use the Japanese version of the CAIT and a cutoff score of 25 when assessing patients for CAI.

\section{Acknowledgements}

The authors wish to express their gratitude to Dr. Claire Hiller for her permission and advice in this study 
and every collegiate soccer athletes who kindly agreed to tale part in this research.

\section{Declaration of Interest}

The authors report no declaration of interest. 


\section{References}

[1]Fong D, Hong Y, Chan, LK, et al. A systematic review on ankle injury and ankle sprain in sports. Sports Med. 2007;37:73-94.

[2]Smith RW, Reischl SF. Treatment of ankle sprains in young athletes. Am J Sports Med. 1986;14:465-471.

[3]Yeung M, Chan K, So C, et al. An epidemiological survey on ankle sprain. Brit J Sports Med. 1994;28:112-116.

[4] Chan KW, Ding BC, Mroczek KJ. Acute and chronic lateral ankle instability in the athlete. Bull NYU Hosp Joint Dis. 2011;69:17-26.

[5]Rijn RM, van O, van AG, et al. What is the clinical course of acute ankle sprains? A systematic literature review. Am J Med. 2008;121:324-331.

[6]Docherty CL, Arnold BL, Gansneder BM, et al. Functional-performance deficits in volunteers with functional ankle instability. J Athletic Train. 2005;40:30-34.

[7]Willems T, Witvrouw E, Verstuyft J, et al. Proprioception and muscle strength in subjects with a history of ankle sprains and chronic instability. J Athletic Train. 2002;37:487-493.

[8]Arnold B, Motte S, Linens S, et al. Ankle instability is associated with balance impairments: a meta-analysis. Med Sci Sports Exercise. 2009;41:1048-1062.

[9]Witchalls J, Blanch P, Waddington G, et al. Intrinsic functional deficits associated with increased risk of ankle injuries: a systematic review with meta-analysis. Brit J Sports Med. 2012;46:515-523.

[10]Hertel J. Functional anatomy, pathomechanics, and pathophysiology of lateral ankle instability. J Athletic Train. 2002;37:364-375.

[11]Hubbard TJ, Kramer LC, Denegar CR, et al. Correlations among multiple measures of functional and mechanical instability in subjects with chronic ankle instability. J Athletic Train. 2007;42:361-366.

[12]Beynnon BD, Webb G, Huber BM, et al. Radiographic measurement of anterior talar translation in the ankle: determination of the most reliable method. Clin Biomech. 2005;20:301-306.

[13]Seebauer CJ, Bail HJ, Rump JC, et al. Ankle laxity: stress investigation under MRI control. Am J Roentgenol. 2013;201:496-504.

[14]Karlsson J, Peterson L. Evaluation of ankle joint function: the use of a scoring scale. Foot. 1991;1:15-19.

[15]Niki H, Aoki H, Inokuchi S, Ozeki, S, et al. Development and reliability of a standard rating system for outcome measurement of foot and ankle disorders I: development of standard rating system. J Orthopaedic Sci.2005;10:457-465.

[16]Niki H, Tatsunami S, Haraguchi N, et al. Development of the patient-based outcome instrument for the foot and ankle. Part 1: project description and evaluation of the outcome instrument version 1. J Orthopaedic Sci. 2011;16:536-555.

[17]Eechaute C, Vaes P, Aerschot L, et al. The clinimetric qualities of patient-assessed instruments for measuring chronic ankle instability: a systematic review. BMC Musculoskeletal Disord. 2007;8:6.

[18]Hiller CE, Refshauge KM, Bundy AC, et al. The Cumberland ankle instability tool: a report of validity 
and reliability testing. Arc Physical Med Rehabil. 2006;87:1235-1241.

[19]Gribble PA, Delahunt E, Bleakley CM, et al. Selection criteria for patients with chronic ankle instability in controlled research: a position statement of the International Ankle Consortium. J Athletic Train. 2014;49:121-127.

[20]Noronha MD, Refshauge KM, Kilbreath SL, et al. Cross-cultural adaptation of the Brazilian-Portuguese version of the Cumberland Ankle Instability Tool (CAIT).Disabil Rehabil. 2008;30:1959-1965.

[21]Cruz-Díaz D, Hita-Contreras F, Lomas-Vega R, et al. Cross-cultural adaptation and validation of the Spanish version of the Cumberland Ankle Instability Tool (CAIT): an instrument to assess unilateral chronic ankle instability. Clin Rheumatol. 2013;32:91-98.

[22]Noronha M, Refshauge KM, Kilbreath SL, et al. Loss of proprioception or motor control is not related to functional ankle instability: an observational study. Aust J Physiother. 2007;53:193-198.

[23]Sawkins K, Refshauge KM, Kilbreath SL, et al. The placebo effect of ankle taping on ankle instability. Med Sci Sports Exercise. 2007;39:781-787.

[24]Wright C, Arnold B, Ross S, et al. Recalibration and validation of the Cumberland Ankle Instability Tool cutoff score for individuals with chronic ankle instability. Arch Physical Med Rehabil. 2014;95:1853-1859.

[25]Koshino Y, Yamanaka M, Ezawa Y, et al. Lower limb joint motion during a cross cutting movement differs in individuals with and without chronic ankle instability. Physical Therapy Sport. 2014;15:242-248.

[26]Yoshida N, Kobayashi N, Masunari A, et al. Changes in the muscle reaction time of ankle periarticular muscles by balance training. J Physical Fitness Sports Med. 2013;2:493-500.

[27]Beaton D, Bombardier C, Guillemin F, et al. Guidelines for the Process of Cross-Cultural Adaptation of Self-Report Measures. Spine. 2000;25:3186-3191.

[28]Delahunt E, Coughlan GF, Caulfield B, et al. Inclusion criteria when investigating insufficiencies in chronic ankle instability. Med Sci Sports Exercise. 2010;42:2106-2121.

[29]Monaghan K, Delahunt E, Caulfield B. Ankle function during gait in patients with chronic ankle instability compared to controls. Clin Biomech (Bristol, Avon). 2006;21:168-174.

[30]Delahunt E, Monaghan K, Caulfield B. Altered neuromuscular control and ankle joint kinematics during walking in subjects with functional instability of the ankle joint. Am J Sports Med. 2006;34:1970-1976.

[31]Futatsubashi G, Sasada S, Tazoe T, et al. Gain modulation of the middle latency cutaneous reflex in patients with chronic joint instability after ankle sprain. Clin Neurophysiol. 2013;124:1406-1413.

[32]Terwee C, Bot S, Boer M, et al. Quality criteria were proposed for measurement properties of health status questionnaires. J Clin Epidemiol. 2006;60:34-42.

[33]Deyo RA, Centor RM. Assessing the responsiveness of functional scales to clinical change: an analogy to diagnostic test performance. J Chronic Dis.1986;39:897-906.

[34]Youden W. Index for rating diagnostic tests. Cancer. 1950;3:32-35.

[35]Landis JR, Koch GG. The measurement of observer agreement for categorical data. Biometrics. 
1977;33:159-174.

[36]Hertel J, Kaminski TW. Second international ankle symposium summary statement. J Orhop Sports Phys Ther. 2005;35:A2-A6. 
Appendix Legends

Appendix 1. The CAIT Questionnaire

Appendix 2. The Japanese version of the CAIT

Table Legends

Table 1. Participant characteristics

Table 2. Retest group characteristics

Table 3. Internal consistency

Table 4. Inspection capability at each potential CAIT cutoff

Table 5. Comparison of CAIT clinimetric properties between studies

Figure Legends

Figure 1. Relationship between the Japanese version of the CAIT score and the Karlsson score $(r=0.604$,

$\left.{ }^{*} p<0.001\right)$. Each point represents an individual subject $(n=111)$.

Figure 2. ROC curve for the Japanese version of the CAIT score. The curve represents the ROC curve, and the diagonal line represents the reference line for the significant ROC curve. ${ }^{*}$ Cutoff value with the highest Youden index. 
Table 1. Participant characteristics

\begin{tabular}{|c|c|c|c|c|c|}
\hline & \multicolumn{2}{|c|}{$\begin{array}{l}\text { CAI group } \\
(n=61)\end{array}$} & \multicolumn{2}{|c|}{$\begin{array}{l}\text { Control group } \\
(n=50)\end{array}$} & \multirow[t]{2}{*}{$p$-Value } \\
\hline & Mean & $\mathrm{SD}$ & Mean & SD & \\
\hline Age (ys) & $19 \pm$ & & $19 \pm$ & & 0.687 \\
\hline Height $(\mathrm{cm})$ & 172.66 & 4.97 & 173.63 & 5.39 & 0.326 \\
\hline Weight (kg) & 66.06 & 4.93 & 67.04 & 6.25 & 0.360 \\
\hline Body fat (\%) & 11.42 & 1.86 & 11.21 & 2.09 & 0.572 \\
\hline CAIT score & 22.56 & 4.89 & 28.56 & 1.65 & $0.000 *$ \\
\hline
\end{tabular}

There is significant difference between two groups $(* p<0.05)$

Table 2. Retest group characteristics

\begin{tabular}{lcc}
\hline & $\begin{array}{c}\text { Retest group } \\
(n=41)\end{array}$ & SD \\
\hline Age (ys) & Mean & \\
Height (cm) & $18 \pm$ & 4.73 \\
Weight $(\mathrm{kg})$ & 171.02 & 5.81 \\
Body fat $(\%)$ & 64.45 & 2.03 \\
\hline
\end{tabular}

Table 3. Internal consistency

\begin{tabular}{lcc}
\hline & $\begin{array}{c}\text { Corrected Item: total } \\
\text { correlation }\end{array}$ & $\begin{array}{c}\text { Cronbach's } \alpha \text { if item was } \\
\text { deleted }\end{array}$ \\
\hline Item 1 & 0.629 & 0.805 \\
Item 2 & 0.760 & 0.796 \\
Item 3 & 0.761 & 0.797 \\
Item 4 & 0.605 & 0.816 \\
Item 5 & 0.502 & 0.825 \\
Item 6 & 0.469 & 0.825 \\
Item 7 & 0.715 & 0.797 \\
Item 8 & 0.488 & 0.823 \\
Item 9 & 0.357 & 0.859 \\
\hline
\end{tabular}

No improvement was observed every time that one item was deleted from the scale, except for item 9 
Table 4. Inspection capability at each potential CAIT cut-off

\begin{tabular}{|c|c|c|c|c|c|c|}
\hline CAIT & $\mathrm{Sn}$ & $1-\mathrm{Sp}$ & $\mathrm{Sp}$ & $\begin{array}{l}\text { Youden } \\
\text { Index }\end{array}$ & $\mathrm{LR}+$ & $\mathrm{LR}-$ \\
\hline 6.0 & 0.000 & 0.000 & 1.000 & 0.000 & NA & 1.000 \\
\hline 7.5 & 0.016 & 0.000 & 1.000 & 0.016 & NA & 0.984 \\
\hline 9.0 & 0.033 & 0.000 & 1.000 & 0.033 & NA & 0.967 \\
\hline 11.5 & 0.049 & 0.000 & 1.000 & 0.049 & NA & 0.951 \\
\hline 13.5 & 0.082 & 0.000 & 1.000 & 0.082 & NA & 0.918 \\
\hline 15.5 & 0.098 & 0.000 & 1.000 & 0.098 & NA & 0.902 \\
\hline 17.5 & 0.131 & 0.000 & 1.000 & 0.131 & NA & 0.869 \\
\hline 18.5 & 0.213 & 0.000 & 1.000 & 0.180 & NA & 0.820 \\
\hline 19.5 & 0.180 & 0.000 & 1.000 & 0.213 & NA & 0.787 \\
\hline 20.5 & 0.246 & 0.000 & 1.000 & 0.246 & NA & 0.754 \\
\hline 21.5 & 0.262 & 0.000 & 1.000 & 0.262 & NA & 0.738 \\
\hline 22.5 & 0.295 & 0.000 & 1.000 & 0.295 & NA & 0.705 \\
\hline 23.5 & 0.459 & 0.000 & 1.000 & 0.459 & NA & 0.541 \\
\hline 24.5 & 0.574 & 0.000 & 1.000 & 0.574 & NA & 0.426 \\
\hline 25.5 & 0.705 & 0.020 & 0.980 & 0.685 & 35.25 & 0.301 \\
\hline 26.5 & 0.852 & 0.220 & 0.780 & 0.632 & 3.872 & 0.189 \\
\hline 27.5 & 0.934 & 0.340 & 0.660 & 0.594 & 2.747 & 0.100 \\
\hline 28.5 & 0.984 & 0.380 & 0.340 & 0.604 & 2.589 & 0.025 \\
\hline 29.5 & 1.000 & 0.620 & 0.380 & 0.380 & 1.612 & 0.000 \\
\hline 31.0 & 1.000 & 1.000 & 0.000 & 0.000 & 1.000 & NA \\
\hline
\end{tabular}

Abbreviations: NA; not applicable, Sn; sensitivity, Sp; specificity, LR+; positive likelihood, LR-; negative likelihood

Table 5. Comparison of CAIT clinimetric properties between studies

\begin{tabular}{lrrc}
\hline $\begin{array}{l}\text { Test } \\
\text { Characteristic }\end{array}$ & $\begin{array}{r}\text { Hiller et al } \\
\text { (cutoff } \leq 27)\end{array}$ & $\begin{array}{c}\text { Wright et al } \\
\text { (cutoff } \leq 25)\end{array}$ & $\begin{array}{c}\text { Japanese version } \\
\text { (cutoff } \leq 25)\end{array}$ \\
\hline Sensitivity & 0.860 & 0.951 & 0.705 \\
Specificity & 0.830 & 1.000 & 0.980 \\
LR + & 4.890 & 27.171 & 35.35 \\
LR- & 0.180 & 0.051 & 0.30 \\
\hline
\end{tabular}




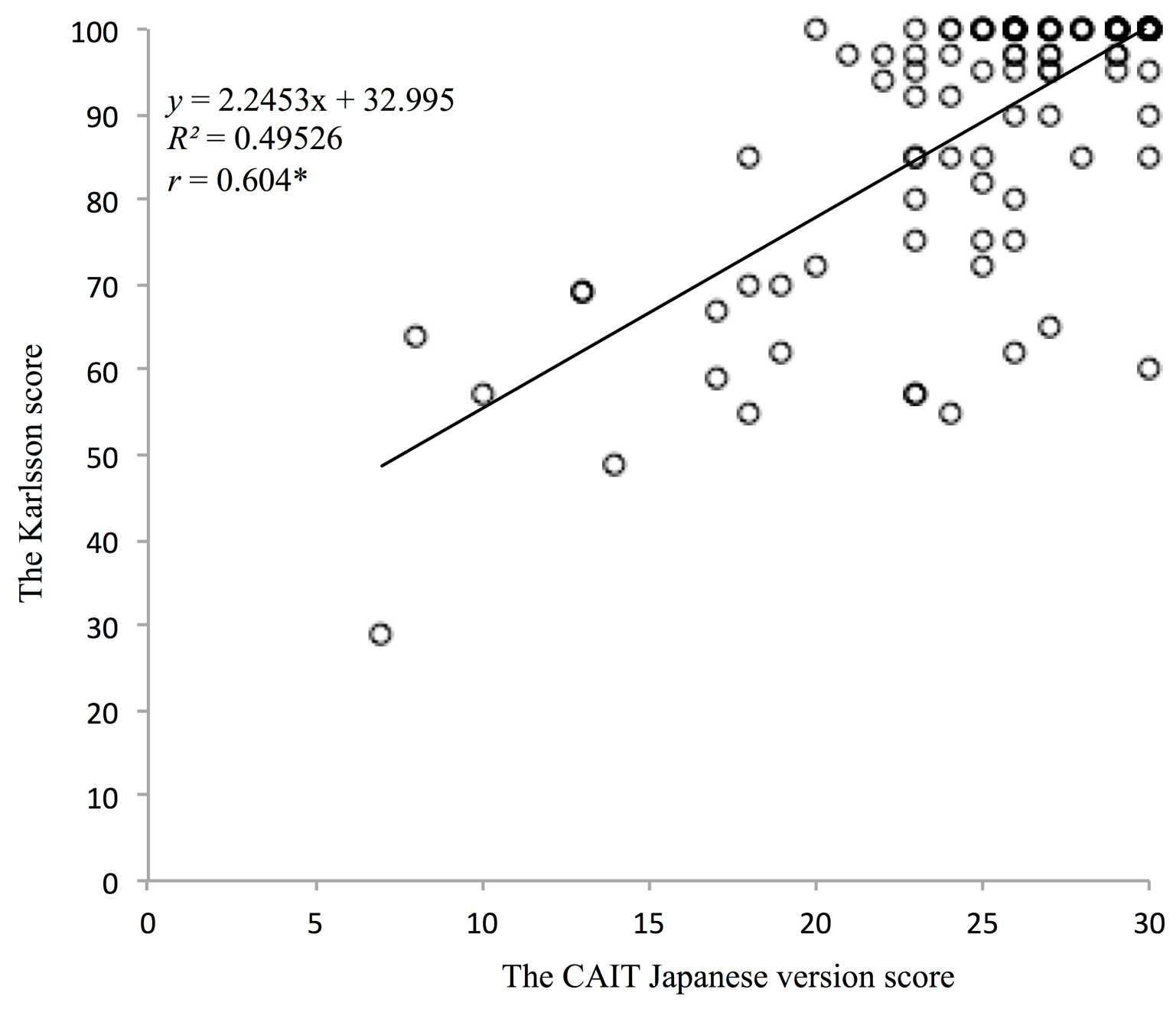




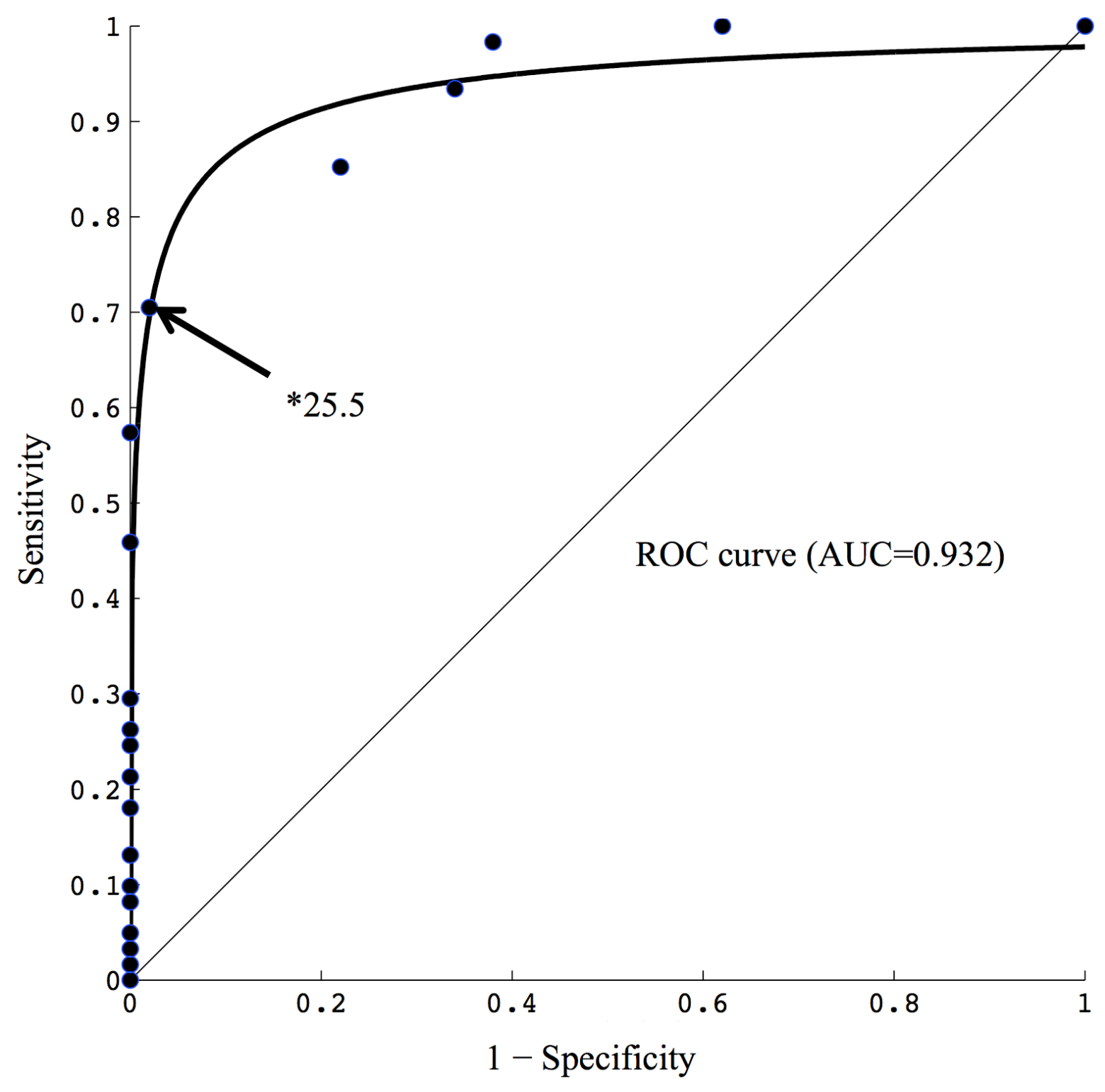




\section{APPENDIX 1: THE CAIT QUESTIONNAIRE}

Please tick the ONE statement in EACH question that BEST describes your ankles.

\begin{tabular}{|c|c|c|c|}
\hline & LEFT & RIGHT & Scor \\
\hline \multicolumn{4}{|l|}{ 1. I have pain in my ankle } \\
\hline Never & $\square$ & $\square$ & 5 \\
\hline During sport & $\square$ & $\square$ & 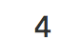 \\
\hline Running on uneven surfaces & $\square$ & $\square$ & \\
\hline Running on level surfaces & $\square$ & $\square$ & \\
\hline Walking on uneven surfaces & $\square$ & $\square$ & \\
\hline Walking on level surfaces & $\square$ & $\square$ & \\
\hline \multicolumn{4}{|l|}{ 2. My ankle feels UNSTABLE } \\
\hline Never & $\square$ & $\square$ & \\
\hline Sometimes during sport (not every time) & $\square$ & $\square$ & \\
\hline Frequently during sport (every time) & $\square$ & $\square$ & \\
\hline Sometimes during daily activity & $\square$ & $\square$ & \\
\hline Frequently during daily activity & $\square$ & $\square$ & \\
\hline \multicolumn{4}{|c|}{ 3. When I make SHARP turns, my ankle feels UNSTABLE } \\
\hline Never & $\square$ & $\square$ & \\
\hline Sometimes when running & $\square$ & $\square$ & \\
\hline Often when running & $\square$ & $\square$ & \\
\hline When walking & $\square$ & $\square$ & 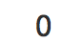 \\
\hline \multicolumn{4}{|c|}{ 4. When going down the stairs, my ankle feels UNSTABLE } \\
\hline Never & $\square$ & $\square$ & 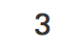 \\
\hline If I go fast & $\square$ & $\square$ & 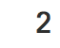 \\
\hline Occasionally & $\square$ & $\square$ & 1 \\
\hline Always & $\square$ & $\square$ & . \\
\hline \multicolumn{4}{|c|}{ 5. My ankle feels UNSTABLE when standing on ONE leg } \\
\hline Never & $\square$ & $\square$ & 2 \\
\hline On the ball of my foot & $\square$ & $\square$ & 1 \\
\hline With my foot flat & $\square$ & $\square$ & 0 \\
\hline \multicolumn{4}{|l|}{ 6. My ankle feels UNSTABLE when } \\
\hline Never & $\square$ & $\square$ & 3 \\
\hline I hop from side to side & $\square$ & $\square$ & 2 \\
\hline I hop on the spot & $\square$ & $\square$ & 1 \\
\hline When I jump & $\square$ & $\square$ & 0 \\
\hline \multicolumn{4}{|l|}{ 7. My ankle feels UNSTABLE when } \\
\hline Never & $\square$ & $\square$ & 4 \\
\hline I run on uneven surfaces & $\square$ & $\square$ & 3 \\
\hline I jog on uneven surfaces & $\square$ & $\square$ & 2 \\
\hline I walk on uneven surfaces & $\square$ & $\square$ & 1 \\
\hline I walk on a flat surface & $\square$ & $\square$ & 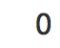 \\
\hline
\end{tabular}

8. TYPICALLY, when I start to roll over (or "twist") on my ankle, I can stop it Immediately

Often

Sometimes

Never

I have never rolled over on my ankle

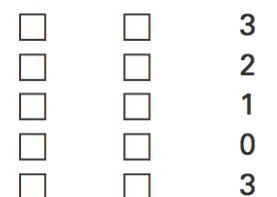

9. After a TYPICAL incident of my ankle rolling over, my ankle returns to "normal"

Almost immediately Less than one day 1-2 days

More than 2 days

I have never rolled over on my ankle

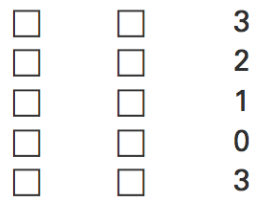

NOTE. The scoring scale is on the right. The scoring system is not visible on the subject's version. 
Appendix 2. The Japanese version of the CAIT.

各質問に対し,あなたの足関節に関して最も当てはまるもの1つに可を付けて下さい

\begin{tabular}{|c|c|c|c|}
\hline & 左足 & 右足 & 点数 \\
\hline 1.以下の状況で足関節に痛みがでますか？ & & & \\
\hline まったくでない & $\square$ & $\square$ & 5 \\
\hline スポーツ中 & $\square$ & $\square$ & 4 \\
\hline 凸凹な地面でのランニング中 & $\square$ & $\square$ & 3 \\
\hline 平らな地面でのランニング中 & $\square$ & $\square$ & 2 \\
\hline 凸凹な地面での歩行中 & $\square$ & $\square$ & 1 \\
\hline 平らな地面での歩行中 & $\square$ & $\square$ & 0 \\
\hline 2.以下の状況で足関節に不安定感がありますか? & & & \\
\hline まったくない & $\square$ & $\square$ & 4 \\
\hline スポーツ中に時々(毎回ではない) & $\square$ & $\square$ & 3 \\
\hline スポーツ中に頻繁に(毎回) & $\square$ & $\square$ & 2 \\
\hline 日常生活中に時々 & $\square$ & $\square$ & 1 \\
\hline 日常生活中に頻繁に & $\square$ & $\square$ & 의 \\
\hline 3.以下の状況で急なターンをした時に足関節に不安定感がありますか? & & & \\
\hline まったくない & $\square$ & $\square$ & 3 \\
\hline ランニング中に急なターンをした時に時々 & $\square$ & $\square$ & 2 \\
\hline ランニング中に急なターンをした時に度々 & $\square$ & $\square$ & ( \\
\hline 歩行中に急なターンをした時 & $\square$ & $\square$ & 0 \\
\hline 4.以下の状況で階段を降りる時に足関節に不安定感がありますか？ & & & \\
\hline まったくない & $\square$ & $\square$ & 3 \\
\hline 急いだ場合 & $\square$ & $\square$ & 2 \\
\hline たまに & $\square$ & $\square$ & 1 \\
\hline いっも & $\square$ & $\square$ & 0 \\
\hline 5.以下の状態で片足立ちをした時に足関節に不安定感がありますか? & & & \\
\hline まったくない & $\square$ & $\square$ & 2 \\
\hline つま先立ちをした場合 & $\square$ & $\square$ & 1 \\
\hline 足裏を床にしっかりとつけた場合 & $\square$ & $\square$ & 0 \\
\hline 6.以下の状況で足関節に不安定感がありますか? & & & \\
\hline まったくない & $\square$ & $\square$ & 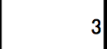 \\
\hline 片足で左右に数回飛び跳ねた時 & $\square$ & $\square$ & 2 \\
\hline 片足でその場で数回飛び跳ねた時 & $\square$ & $\square$ & 1 \\
\hline 片足で高く1回ジャンプ着地した時 & $\square$ & $\square$ & 0 \\
\hline 7.以下の状況で足関節に不安定感がありますか？ & & & \\
\hline まったくない & $\square$ & $\square$ & 4 \\
\hline 凸凹した地面での走行時 & $\square$ & $\square$ & 3 \\
\hline 凸凹した地面でのジョギング時 & $\square$ & $\square$ & 2 \\
\hline 凸凹した地面での歩行時 & $\square$ & $\square$ & 1 \\
\hline 平らな地面での歩行時 & $\square$ & $\square$ & 0 \\
\hline 8.通常,足関節を捻りそうになった時,それを止められますか？ & & & \\
\hline すぐに止められる & $\square$ & $\square$ & 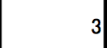 \\
\hline たいていは止められる & $\square$ & $\square$ & - \\
\hline たまに止められる & $\square$ & $\square$ & 1 \\
\hline 止められない & $\square$ & $\square$ & 0 \\
\hline 足関節を捻ったことがない & $\square$ & $\square$ & 3 \\
\hline 9.足関節を捻った後,通常の状態に戻るまでどれくらいかかりますか？ & & & \\
\hline たいていすぐ戻る & $\square$ & $\square$ & 3 \\
\hline 1日以内 & $\square$ & $\square$ & 2 \\
\hline 1-2日 & $\square$ & $\square$ & 1 \\
\hline 2日以上 & $\square$ & $\square$ & 0 \\
\hline 足関節を揄ったことがない & $\square$ & $\square$ & 3 \\
\hline
\end{tabular}

NOTE: The scoring scale is on the right. The scoring system is not visible on the subject's version. 